\title{
ANTHROPOLOGICAL STUDY OF MEMOIRS OF ETHNIC MINORITY MEMBERS (ON THE EXAMPLE OF THE LEMKO DIARIES)
}

\author{
METHODOLOGICAL PROPOSALS
}

\section{by Patrycja Trzeszczyńska-Demel}

The basis of this article are reflections on the analysis of the Lemko personal document literature, which was the subject of my Ph.D. thesis dedicated to the collective memory of the Lemko community in Poland and Ukraine. ${ }^{1}$ Lemko people, displaced from the Low Beskid Mountains in the years 1944-1947 to Soviet Ukraine and to the western and northern regions of Poland, inspire numerous sociologists, ethnologists, and historians. ${ }^{2}$ For years, certain problems in this regard have been thoroughly exploited, especially those concerning the national identity and ethnic renaissance. On the other hand, some issues are omitted and neglected, for instance the issue of memory (used by the Lemkos for the self-affirmation purposes), increased drive for self-discovery and the efforts undertaken by the Lemkos to take a stand towards the commemorating practices made by he Polish and Ukrainian society. Scrutinizing the Lemkos' memory was my primary objective.

1 In 2013, my book, Łemkowszczyzna zapamiętana: Opowieści o przeszłości i przestrzeni (Lemkivshchyna Remembered: Stories about the Past and the Space) (Jagiellonian University Press, series: "Anthropos"), was published. It was based on my Ph.D. dissertation. The following article is an extended version of the discussion on my application of the biographical method, which makes one of the subsections of the book.

2 In this text, I write about the Lemkos as members of an ethnic minority. The following methodological suggestions can also be applied to the written memories of other minorities, including the national minorities. 
I analyzed Lemko autobiographies, diaries, memoirs, chronicles, and collections of memoirs. The set of texts that I have collected includes 66 publications, published as separate books in Poland and Ukraine, after 1989 and 1991, respectively. These accounts have one or more authors and were published in Polish, Ukrainian or Lemko.

I dealt with the narrative practices applied by the Lemko-their structure, content and ways of using them in group self-presentation strategies. As a self-presentation I understand here the cultural representation of the group and its past, where it is the past whose preservation is a prerequisite for the subsistence of the group. ${ }^{3}$

For an anthropologist, individual memoirs are a valuable source of ethnographic nature. Treated collectively they represent a multi-voice message of a minority group. Following the assumption of the cultural self-presentation of the minority group, I aimed at investigating the mechanisms of constructing the images of the past-within the so-called memory communities (cf. Nijakowski, 2006, pp. 32-33)-co-ordination of the content of these images and using them for the purposes of the community. My goal was also to answer two questions: 'What do Lemko texts say?' (what the course of their reconstruction of the past is, in what way the authors restore it to themselves and to their readers) and 'How do they say it?', in what way individual and collective self-presentation is conducted in them.

\section{$\cos$}

Lemko memoirs are embedded in a number of key topics. The chief motif is the displacement and its consequences: eradication, degradation of the ethnic space and rupture of their ties with their homeland. The authors' goal-which they state explicite-is uttering the truth about the fate of the Lemko and so the individual perspective and biography is exceeded by the perspective of the community. These texts are dominated by the desire to perpetuate the past for future generations. In their autobiographical plan, the authors take up a settlement with their own life, serving the understanding of the decisions taken in the past, the entanglement in external circumstances, and the summary of the choices made. Sometimes, they explicitly express the need to fill in the blank spots in the Lemko historiography, to take up disputes with the existing historical narratives

3 See: the understanding of self-presentation in the Lemko literature as recognized by Helena Duć-Fajfer; in her opinion, in this context, self-presentation is a "demonstration of Lemko problems in all their extent, in the tone of emotional saturation, it is coming out of the isolation, confronting the Lemko world with the ideas of the center, an attempt to initiate dialogue." 
(mostly elaborated by Polish and Ukrainian researchers), to leave for the future generations the inheritance consisting in materials with historical value, going beyond the family framework, and thus to fulfill the obligation towards their ancestors, and to preserve the continuity of the message, affixing it with didactic values.

Lemko memoirs do not constitute a single set. Within them, there can be distinguished two principal trends that indicate the dominant assumption of the authors: autobiographical works associated with the predominance of topics regarding the personal past (autobiographies, memoirs and collections of loosely-related impressions $)^{4}$ and historiographical/reporting works, among which I enumerate manuscripts of historiographical ambitions (village monographs, self-defense Lemko publications and chronicles). ${ }^{5}$ The analysis of these accounts showed that the authors use in their design different memory 'ingredients' (or even reach into separate memories that are consistent only in respect of certain items), operating on both sides of the Polish-Ukrainian border. What is more, the narrators-eyewitnesses of the described events and their participants use different 'ingredients' than the representatives of successive generations undertaking the efforts to save the history of their ancestors. At the level of argumentation presented by the authors, what was interesting for me was how these texts bring back the past, how they perform its reconstruction and axiologization, i.e. how and to whom they speak, what rhetorical means they use for this purpose, what key-words they operate, how they construct the message for the sake of specific memory strategies. I was striving to capture the shape of the selfpresentation of both the author and the community of memory (as well as the narrative community), which the author represents and on whose behalf he writes about the Lemko past.

By using a modified version of the biographical method, which I will describe in detail further on, I managed also to identify the authors' ways of using the works of their predecessors, filling the gaps in the family transfer of knowledge-especially by authors representing the generation of children of the displaced Lemko citizens-through tapping into the scientific and popular texts, oral and written accounts of the members of the community in which the authors are situated and which they represent.

4 Cf. autobiographies (e.g. Murianka, 2007; Maślej, 2008; Makuch, 2007), diaries (e.g. Barna, 2004; Fecica, 2004; Ołenycz, 1993; Chomiak, 1995), impressions (e.g. Wozniak, 2010; Trojczak, 2009; Kuziak, 1999).

5 Cf. village monographs (e.g. Barna, 1996; Starczak-Wawryczyn, 2009), self-defense (e.g. Zwoliński, 1994; Ołenycz, 2003; Barna \& Gocz, 2005), chronicles (e.g. Cne mi sia... 2006; Monczak, Połyniak, \& Juśkiw 2006; Muszynka, 2001; Hałyk, 2009). 
Written Lemko memoirs are linked by a strong imperative to immortalize the details of the past world, hence the texts reveal the passion for collecting facts, names, dates, topographical details, everyday objects, equipment found once in Lemko farms, customs and rituals. These annalistic devices make it possible for the author and the 'ethnic' readers to re-capture the now-defunct past and preserve the memory of it for the sake of the subsequent generations. In addition to this, the authors seek to perpetuate stories about real life in Lemkivshchyna-prior, during and after the displacement, when they got settled on the new lands. Their statements are supported by the reference to the enclosed archival and contemporary photographs, copies of documents, songs, texts etc.

Prior to writing down and publishing them, when it became possible, these accounts functioned in oral circulation. Authors taking up 'working' with the 'matter' of the past made a retrospection of the events that happened even decades before. They also had to deal with the phenomenon of stratification resulting from multiple conversations, discussions with family members and compatriots, readings, traveling to the place of birth. The narrative being the effect of such process and presenting their own lives as well as other people's lives was based on the biography of the authors, their relatives, neighbors from their native village, circle of friends. It was also affected by the distance in time that has elapsed since the occurrence of the events the experiences described; the reflections accumulated through the years and the evaluation of past life; the distortions and gaps resulting from the imperfections of human memory, later experiences, conversations, interference caused by the memories of others-heard or read. Other factors influencing the view of the past and the shape of the text are the present goals and the urge felt by the author-and also by the community represented by him/her-to take a position and formulate a clear identity message, to express the ethnic aspirations, etc. Another important issue is the rhetorical and stylistic editing and sometimes also-though rather rarely in case of Lemko accounts, issued mostly by the authors at their own expense- the external interference (on the part of editors, reviewers).

$\cos$

With all this in mind, and recognizing that the nature of these texts does not reduce their empirical value for the researcher interested in memory and cultural self-presentation, I commenced an analysis of Lemko memories using the biographical method. This method, sometimes referred to as the method of biographical documents, in recent years has been most predominantly applied for the analysis of the material induced by the investigator. However, in my opinion, it can be used equally successfully, after some 
modification of assumptions, to study written material, non-induced e.g. in a competition.

A researcher reaching for the published memoirs becomes a recipient equal to any reader of the text, in this case primarily the ethnic-Lemko reader, but also a representative of the majority population, Polish or Ukrainian. The absence of direct presence of the researcher, the lack of pressure, and distance, ensure that the narrator has a much greater freedom in the reconstruction of the past, in mining the most crucial events and attributing importance to them at his/her own pace, away from the recorder being a part of every interview. On the other hand, as emphasized by the advocates of narrative interviews, written narration by definition is devoid of spontaneity, and therefore we are not able to capture the world of meanings of the author, unmediated by external supports of the memory that is susceptible to transformations and moves away from the 'pure' individual past. The selection of the material used by the writers to create a narrative about the past, self-censorship, gaps resulting from the omission of personal details to conceal embarrassing or not-so-glorious moments of their lives or the life of a group reduce the value of such statements, flatten the obtained image, partition it, and form only a variation on what the narrator would tell us during an interview. However, if we are interested in the conscious and intentional self-presentation understood as a strategy of the author and located in the plan of the text andthrough him/her-the strategy of the group in which this person is located and on behalf of which he/she speaks, then the written texts are an excellent source for tracking it. When we are after the statement expressed by a given environment about themselves, when we wish to look at the self-analysis of the representatives of some ethnic group or minority, published memoirs reveal the mechanisms of the construction of such statements better than oral narratives, since they are intended to be spotted by someone other than the members of their own environment. An analysis of written, published memoirs enables us to see what the investigated group wants to say to the majority among which it is situated (if the book is published in the language of the majority and there is a chance that its representatives will reach for it), or what it wants to pass on to the posterity, and therefore, what values are fundamental for the authors.

The analysis of biographical material (biographies and autobiographies, diaries, memoirs, letters) has long been in the area of interest of sociologists (Kaźmierska, 2004). Ethnologists discovered its use relatively late (Kabzińska, 2003). It allows one to reconstruct the meanings assigned by people to their past experiences and thus follow the transformation of human memory, group symbols, methods for the construction of social reality, etc. 
The precursor of the life study method was Florian Znaniecki, who together with William Thomas used the personal documents of Polish immigrants in the United States to show the process of social change and adaptation to life in exile. In the introduction to the third volume of the classic work, The Polish Peasant in Europe and America, the researchers emphasized "the superiority of life-records over every other kind of material" analyzed by the sociologist and its relevance for the general characteristics of the social processes (Thomas \& Znaniecki, 1918, p. 7). The analysis of life-records, popularized by the above-mentioned work, has become one of the main research methods in sociology performed by the 'Chicago School' in the 1930s and 1940s (Kaźmierska, 2004, p. 71). The ideas of Thomas and Znaniecki in the 1930s were continued by Józef Chałasiński. Both before World War II and after it, a number of competitions were organized in Poland for memoirs, addressed to a particular social class or group: peasants, workers, emigrants, doctors, young intellectuals, rural activists, etc. In the years 1945-1975, 1043 competitions for diaries were held (Wojtkowiak, 2003, p. 87). In the 1960s and 1970s, the biographical method, however, lost its popularity. One of the advocates encouraging the use of personal documents in sociology (but only as supplementary material) was Jan Szczepański, who defined this research strategy as follows: "The life study method is such sociological research in which, to solve the problem posed, the researcher collects only materials containing the accounts of people presenting their participation in the events and processes which are the subject of the research, and on the basis of these reports a description of the given processes is elaborated and the explanatory hypotheses are proposed" (Szczepański, 1971, pp. 577-578). The return to the method of personal documents analysis occurred in the 1980s (see, inter alia, Rauch, 1986) and can be observed today in many centers, among which excels the Institute of Sociology of the University of Łódź, promoting the life study method founded on the German achievements in sociology, especially those attributable to Fritz Schütze, i.e. the method of conducting and analyzing a narrative interview (Kaźmierska, 2004).

The 'German School' developed in the biographical analysis new methodological reflection on the ground of phenomenology, ethnomethodology and symbolic interactionism based on the assumption of the social construction of reality by acting individuals (cf. Apitzsch \& Inowlocki, 2000). A significant contribution to the development of this reflection resulted due to the popularization of audio and video recording devices. Today, the 'German School' is dominated by two orientations of biographical research, which draw attention to striving to minimize the impact of the researcher on the creation of autobiographical material, namely the narrative interview 
method elaborated by Schütze and objective hermeneutics proposed by Ulrich Oevermann (cf. Kaźmierska, 2004, p. 71; Urbaniak-Zając \& Kos, 2013).

The basic ontological assumptions essential when applying the biographical method are contained in the concept of "humanistic coefficient," derived from Znaniecki (1936), regarding the role of subjective factors, such as attitudes of individuals, their assessments, criteria of evaluation and their equivalence with the objective cultural values. In their practice, researchers should take into account the importance attached to social phenomena by people experiencing these phenomena. It is also associated with the process of biographical acquiring of knowledge about the self, and therefore with the category of identity: "Biographical narrative shows how the continuity of our 'being ourselves' is generated. Biographical constructions are based on the knowledge that an individual has of himself/ herself and without any external influence. This knowledge is constantly evolving in different interactive situations. The identity emerges in the process of interaction; an individual, talking about his/her relationships with other people, defines himself/herself. [...] Telling the story of one's own life story is tantamount to creating an interpretation of biographical events. The facts, invoked from memory and recreated, have been interpreted by the narrators, 'subjectively filled with sense' according to the specific structure of meanings. Constructing the autobiography we invoke the images of the past, but also design our future actions. Reading out the applied interpretative schemes reveals the strategies used to build identity and the way in which an individual participates in social life" (Szlachcicowa, 2003, pp. 13-14).

Methodological assumptions for the analysis of autobiographical material result directly from the ontological assumptions and relate to the possibility of using it in the study of the meanings that their authors attach to the surrounding reality (including the ethnic reality) of images, autostereotypes and group symbols. Therefore, the allegations formulated towards the method of biographical documents (imputing the lack of representativeness, objectiveness; the extraordinariness of the author in relation to the other members of the community who do not make the literary effort; simplifications, distortion of the depicted reality, fictitiousness of the material, etc. (Szczepański, 1971, pp. 603-605) do not discredit it in terms of the analysis of the written Lemko memoirs as a manifestation of cultural self-presentation. Data obtained using the biographical method serve not only presenting a subjective reality, but also including it in the context of time and interactions. The interest in this mechanism of assigning meanings in the practice of self-presentation and their interpretation approximate the researcher to the methodological approach appropriate 
for interpretive interactionism, which explores the meanings assigned to the lived experience by interacting individuals and examines how it is experienced and expressed, interpreted and understood (Denzin, 2001). This also brings the research perspective closer to interactive hermeneutics, in which the researcher focuses on discovering and interpreting meanings that are created and lived by the members of the studied group (cf. Denzin, 1990, pp. 56-57).

According to Szczepański (1971, p. 582), personal documents are particularly important for sociology and a special place is reserved among them for autobiography: "In the broad meaning of the term 'personal document,' we include in this category not only all kinds of autobiographies, diaries and memories, but also letters, literal transcripts of testimonies, interviews and other documents containing a projection of the states of mind of a person (projective documents). However, we can limit this definition and enumerate among personal documents important to sociological research only those written statements that report the participation of the writer in a social situation, that include the personal opinion of the author concerning these situations, a description of the events that took place within it, and a description of the behavior of the author. Only the presence of all these elements in a document makes it valuable for sociological research." It seems that this criterion is fulfilled by Lemko autobiographies and memoirs. And although autobiographies, according to Szczepański, illustrate more fully the entanglement of the individuals in the processes of social life, not in a piecemeal fashion as is the case of memoirs and diaries, I decided to include in the analysis also the latter. ${ }^{6}$ During the analysis of Lemko documentary literature I used the technique of narrative interview analysis, modified for the purpose of the study of written material.

Narrative interview is a combination of different types of biographical research due to the subject highlighted by Ingeborg Helling: biography as a topic or as a means. In this approach, the interview is analyzed with attention to what people say and how they do it. It is characterized by the principle of openness, assuming refraining from specific research hypotheses and focusing on the process of data collection (the person examined determines the boundaries of the subject of studying) and the principle of communication, according to which the structure of expression of the interviewee should not be disturbed (Prawda, 1989, p. 88). Daniel Bertaux (1990, p. 71) distinguishes other groups of autobiographical utterances. In his view, given their research usefulness, they perform the searching,

6 On the subject of genre and terminology distinctions see Sławiński (2002, pp. 50-51) and Głowiński (2002, p. 369). 
analytical or expressive function. This last one seems to me to be particularly useful in defining the tasks of autobiographical material for the research on the issue of cultural self-presentation. It is associated with the hermeneutic approach, highlighted by Bertaux, towards autobiographical statements, which aims to capture the level of meaning that the narrators want to convey. This orientation Bertaux presents in opposition to the ethno-sociological one, which focuses on references, standards, and processes of social life visible in the autobiographical material (ibid., p. 76).

Kaja Kaźmierska (1997), describing the narrative interview tool, stresses that its essence is to obtain life-stories in the form of a spontaneous, uninterrupted narrative, during which the researcher does not intervene by posing questions. The person interviewed is neither a sociological respondent nor an ethnological informant, but the narrator, who creates his/ her story. Depending on the research topic, we get a compact account of the life of the narrator, or only its fragments. However, Iwona Kabzińska, speaking from the position of an ethnologist, draws the attention to the limitations of narrative interview, overlooked by the proponents of this tool. Indeed, for many interviewees, presenting their biography is a serious problem, hence they expect assistance in the form of questions asked by the researcher, which inevitably leads to going beyond the directive of narrative interview and moving towards a free or in-depth interview, as well as steering the conversation and imposing the subject. This may induce the lack of reflection on the interviewee's life, the absence of experiencing the verbalization of one's own memories, not to mention the lack of openness and trust to the researcher who is a stranger, shyness, problems with memory, lack of interest in the history of one's family or social group (Kabzińska, 2003, pp. 44-45). Moreover, it seems that indicating to the interlocutor the plan to conduct an interview violates the requirement of the interview spontaneity, so strongly emphasized by the proponents of this method-the narrator has the time for the initial preparation of the story before it is told. The analysis can also be affected by the interviewee's previous experience in telling stories of his/her life, e.g. to journalists or other researchers, which means practicing some schemes of constructing statements about one's biography and distorted spontaneity of the interview.

The analysis of the communication schemes of a biographical interview is based on distinguishing its narrative, argumentative and descriptive parts. This allows the researcher to highlight two planes in the stories: the narrative (also housing the descriptive part) and the argument, and thus to recognize the past experience from the present attitudes towards 
them, and also to trace the 'biographical work' of the narrator. ${ }^{7}$ In the narrative part, the interviewee recounts his/her experiences by embedding them in some context. For the researcher, it is important whether the narrative has sufficiently detailed descriptions, describing interactive scenes, citing one's own statements and those expressed by others, thanks to which the text has a clearly identifiable subject of biography, contains a sequence of events and experiences, and poses a reference to the framework of social processes. Kaźmierska (2004, pp. 79-89) says about these elements, "In the narrative, its author reconstructs the processual course of experiences, and in the argumentative part, he/she makes an attempt, from the present perspective, to try to explain to himself/herself and the listener the motives for the past actions, to present theories about his/her own identity, and to evaluate his/her life."

Having analyzed the communication schemes, the researcher goes to the structural analysis of the text, which allows for distinguishing the following elements: 1) structure in the background (a story plaited into the mainstream of the narrative, whose purpose is to provide the explanation or clarification); 2) the so-called overrides or gaps in the story; 3 ) theoretical comments (illustrate the current attitude of the narrator to the past events and also serve formulating assessments and commenting); 4) argumentative comments (at the end of the narrative parts; meant to explain past problems and determine the attitude of the narrator towards them); 5) coda (summary of the reconstruction of experiences, linking them with the present perspective, formal conclusion of the interview) (Kaźmierska 2004, pp. 71-96; Helling, 1985, pp. 105-108).

I am not going to deal with the detailed procedure of the narrative interview analysis here, however, what seems significant to me are the comments on the role of the researcher during the interview, to some extent

7 Kaźmierska (2009, pp. 34-35) defines biographical work as "making an effort of interpreting biographical experiences in relation to one's own identity, images of oneself, behaviors, activities undertaken or not. Working on the biography continues throughout life, however, it becomes more intense when a person is subjected to difficult and unexpected experiences forcing a redefinition of identity, change of the way of life [this involves entering the trajectory within the meaning attributed by F. Schütze-P.T., see below]. One of the circumstances enhancing this work may be the need, appearing at a certain point in the life cycle, to give coherence to the whole biography, where different life experiences are not conducive to its consistency or disrupt it." Such a need may generate an effort to take up a retrospection and describe one's experiences in the form of memoirs or a diary, which happens to the Lemko authors in the mature stage of life. Biographical work can have both the individual and collective dimension. It seems that the characteristic feature of the biographical work of the Lemko generation writing memoirs is its collective dimension and that it is subject to collective interpretations that make a return to the past-a common experience of this generation-possible. 
similar, as I think, to the role of the reader of Lemko memoirs. Although the impact of the researcher on the narration is minimal, his/her presence shapes the secondary order of the display of experiences, the dimension of generalization, synthesis, evaluation, and forms of self-presentation. In my opinion, Lemko written self-presentative memoirs assume a similar dialogical form, and the potential presence of the reader in the text ultimately affects its shape.

The assumption concerning the homology between the structures of experience and the order of talking about them refers to the model situation of spontaneous narrative, not thought out and not rehearsed, i.e. the narrative interview situation. In the course of such interview, different phases of the biography are recreated in the narrative in the same order in which they took place in the biographical experience. As pointed out by Kaźmierska (2004, p. 78), "the task of the narrative is to provide information about the processual course of experiences in the biography, thanks to which the researcher can analyze the phenomena he/she finds interesting not as a description of static states, but, referring to the concept of 'natural history' $[\ldots]$, through indicating how the phenomenon arose, developed and eventually disappeared." The interview, under this approach, shows the continuity of biographical experience and reconstruction of events. In the written narrative, this mechanism may seem quite different. Having some time to think about the selection of events as well as the possibility of multiple changes and shifts within the framework of the narrative (corrections, editing) cause that the reconstruction of biographical experience is devoid of the element of spontaneity and thus a concern can be raised doubting its usefulness for the biographical analysis. Nevertheless, this does not disqualify, to my mind, the usefulness of autobiographical sources derived from the memory of ethnic minority's self-presentation strategies, and even increases their rank.

What seems to be common in the structure of the interview and the written accounts is embodied by the process structures highlighted by Schütze and the mechanism for determining the communication schemes. Process structures cover the course of biographical experience shown in the interview narration: 1) biographical action schemes (characterized by intentionality of the undertaken projects); 2) trajectories (experience involving the entanglement of individuals in external factors, which are not controlled by them, but which determine their decisions and choices, often associated with trauma and powerlessness towards their position (the experience moves from intentional action in the direction of experiencing); 3) institutional patterns (subjecting the actions of the individuals to institutionally specific patterns, which are accepted and implemented by them); and 
4) biographical metamorphoses (sudden positive changes in the lives of individuals, introduced otherwise than through biographical patterns of action, often associated with the reconstruction of their identity). In the analysis proposed by Schütze, there is an important division of the narrative into parts: I-the narrator speaks and the researcher listens actively; II-the narrator clearly finishes an utterance and the investigator asks immanent questions (related to the content of the narrative) and external questions (related to the research problems); and III-theorizing of the narrator's experiences (argumentation is included in this part) (Kaźmierska, 2004, pp. 84-86; Prawda, 1989, pp. 83-87; Riemann \& Schütze, 1991, pp. 333-357).

The narratives, which I analyzed do not fit unambiguously within one of the above-distinguished processual structures. Lemko memoirs describe multiple aspects of the narrators' lives, and subjecting them to a review from the perspective of one of the processual structures planes would require focusing on the fate of the individuals', whereas the structures interesting from the point of view of the Lemko cultural self-presentation are precisely those structures that relate to the community and to the collective aspect of portraying the 'ethnic world' by Lemko authors. This also leads to a technical difficulty-Schütze developed his methodology to fit the needs related to analyzing the material collected via the narrative interview technique. The content of the interview is inherently shorter, less structured, chaotic, subject to a greater degree of ad hoc mechanisms of selection of material, than it is in the case of 'cold-told' accounts, where the author constantly has the insight into a systematically emerging narrative presentation of the substance (Piotrowski, 2003, p. 173). Hence, the analysis of the whole of the narrative from the perspective of processual structures does not seem purposeful to me (except one of these structures: the trajectory-embracing in the case of Lemko authors the displacement and its consequences and, instead of action, experiencing based on the accruing deficit of control felt by the individuals affected irrespective of their will (Prawda, 1989, p. 85). It seems that a more relevant concept as regards such cases would be the concept of the autobiographical narrative vectors. The set of such vectors consists of several categories of analysis, including, inter alia, overrides (associated with the act of pushing traumatic events out of the memory, both in experiencing and in the narrative), rooting in the history (descriptions of individual and collective experiences of the group in relation to the argumentative structures of historical, macro-social, and ideological nature facilitate locating these experiences in a wider context) and embedded in the milieu (the primacy of the 'locality,' description of the life environment, the immediate surroundings, and references to the history and theory are only of secondary importance serving the construction of arguments and 
comments), which define the different interpretation attitudes of the narrators towards the events described. A manifestation of this is the organization of the sense of experiences, evident in the way of building the structure of the description and commentary on the presented events. The narrative also has a 'supra-local' character, going beyond the individual system of experience and reflecting the arrangement proper for the group experience, which grants the content of the narrative the elements embodying the collective identity (Piotrowski, 2003, pp. 174-175).

At the level of the narrative structure, an interview and a written story are an interpretative event (Filipkowski, 2007, p. 14), in which the narrator makes the selection of the material and takes up an effort to condense the content to the size of a report. He/she also performs the interpretation of the described events and experiences as well as an evaluation of the past decisions and choices. The narrator must take a position resulting from the attitude to his/ her own biography assumed at the time of constructing the narrative account.

What autobiographies lack and what characterizes a narrative interview is a dynamic retrospection (Prawda, 1989, p. 84) and the ongoing generation of meanings in an interview situation. In the case of a published report, once the interpretation of the events and experiences of the narrator is completed, it is no longer available to verification, and the biographical work is done. What is more, a researcher dealing with written autobiographies or memoirs has no possibility to record and analyze the nonverbal behavior accompanying the narrative. Such researcher cannot find out what emotions accompanied the retrospection, which would be useful in supplementing the research material, especially in view of the principle of considering the narrative in terms of 'how.'

The thing that can make narrative interview closer to autobiography or memoirs, is the method of analysis used in case of the interviews. It seems to me that some of its elements can be used when working with the Lemko memories. Under this procedure, it is necessary to describe the dependencies and inter-relationships between the processual structures that build up the whole biography, and then to determine which of them are common also among other narratives. The next step is the so-called contrasting comparison of categories generated from the first text with the categories of the remaining accounts, which allows to showcase the theoretical diversity of the examined material. This enables elaboration of a theoretical model, the aim of which is to display the relationship between the biographical and social processes and which is verified by theoretical saturation, and therefore such a situation when consecutive portions of the study material do not bring cases that do not align with the model (Kaźmierska, 2004, pp. 86-89). 
One more similarity between the two types of biographical material stems from the opinion expressed by Schütze that subjective meanings the researcher wants to analyze can be expressed only in the language of the narrator, and only when he/she has the opportunity to express his/her thoughts in a context in which he/she understands them. What is more, the narrator must take a stand towards the things he/she states (Helling, 1985, p. 103). This is possible also when writing down memories.

As pointed out by Iwona Kabzińska (2003, pp. 49-50), “biographical materials may be an excellent starting point for research on the attitude of the people and/or groups we are interested in to the space and special places highlighted in it, and on the sense of rootedness and the phenomenon of 'small homelands.' Extremely valuable sources of information in this case are the autobiographical accounts of people who, in different circumstances, have been forced to leave (permanently) the family home, with which they were linked by very strong emotional bonds."

According to Barbara Kubis (2007, p. 57), the biographical method facilitates carrying out "individual analyzes of the culturally imposed patterns of self-identification." Getting to know the fate of individuals, extracted from personal documents, allows one to link the fate of these individuals with the community they belong to (ibid., p. 65). The biographical method ensures the chance to capture, on the one hand, the individual realization of cultural patterns, and on the other hand, the axio-normative system of the community represented by the author. I consider the personal documents literature created by the representatives of the minority community as an excellent source for tracking the ways of constructing a cultural self-presentation, an ethnic image, based on the memory and components for its development.

\section{References}

Apitzsch, U., \& Inowlocki, L. (2000). Biographical Analysis: A ‘German' School. In P. Chamberlayne, J. Bornat, \& T. Wengraf (Eds.), The Turn to Biographical Methods in Social Science: Comparative Issues and Examples (pp. 53-70). Series: The Social Research Today, Vol. IV. London - New York: Routledge.

Barna, A. (2004). Z pamiętnika wysiedleńca. Legnica: Wydawnictwo Atut.

Barna, A. (1996). Kawatczyk ternystoj istoryi seła Czorne na Lemkowyni 1870-1970. Lihnycia: Stowarzyszenie Łemków w Legnicy.

Barna, A., \& Gocz, F. (2005). Lemky w borbi za swoju i neswoju swobodu. Lihnycia - Zyndranowa: Wydawnicza ATUT - Wrocławskie Wydawnictwo Oświatowe. 
Bertaux, D. (1990). Funkcje wypowiedzi autobiograficznych w procesie badawczym. In. J. Włodarek, M. Ziółkowski (Eds.), Metoda biograficzna w socjologii (pp. 71-81). (S. Jakóbczyk, Trans.). Warszawa - Poznań: Państwowe Wydawnictwo Naukowe.

Chomiak, R. (1995). Nasz łemkowski los. Nowy Sącz: Sądecka Oficyna Wydawnicza Wojewódzkiego Ośrodka Kultury.

Cne mi sia za tobom, moja Łemkiwszczyno. (2006). Drohobycz: Wydawnyctwo KOLO.

Denzin, N.K. (2001). Interpretive Interactionism. Series: Applied Social Research Methods, Vol. 16. London: Sage.

Denzin, N. K. (1990). Reinterpretacja metody biograficznej w socjologii: znaczenie a metoda $\mathrm{w}$ analizie biograficznej [Reinterpretation of the biographical metod in sociology: meaning and method in biographical analysis]. In J. Włodarek \& M. Ziółkowski (Eds.; N. Nowakowska, Trans.), Metoda biograficzna w socjologii (pp. 55-69). Warszawa - Poznań: Wydawnictwo Naukowe PWN.

Duć-Fajfer, H. (2007). Etniczność w ekspozycji literackiej: Odwołania rocznicowe. Rocznik Ruskiej Bursy, 3, 21-27.

Fecica, P. (2004). Staryj Łemko opowidat'. Krakiw - Ternopil: A. Fecica.

Filipkowski, P. (2007). Historia mówiona i wojna. In S. Buryła \& P. Rodak (eds.), Wojna: Doświadczenie i zapis—nowe źródła, problemy, metody badawcze (pp. 1335). Kraków: Towarzystwo Autorów i Wydawców Prac Naukowych Universitas.

Głowiński, M. (2002). Pamiętnik [entry]. In J. Sławiński (Ed.), Słownik terminów literackich (p. 369). Wrocław - Warszawa - Kraków - Gdańsk - Łódź: Zakład Narodowy im. Ossolińskich.

Hałyk, J. (2009). Łemkiwszczyna-kraj naszych predkiw. Iwano-Frankiwśk: Misto NW.

Helling, I. (1985). Metoda badań biograficznych. (K. Droździał \& J. Włodarek, Trans.). Kultura i Społeczeństwo, 3, 93-114.

Kabzińska, I. (2003). Metoda biograficzna i jej zastosowanie w badaniach etnologicznych. In J. Kowalska, S. Szynkiewicz, \& R. Tomicki, Czas zmiany, czas trwania: Studia etnologiczne (pp. 39-61). Warszawa: Instytut Antropologii i Etnologii Polskiej Akademii Nauk.

Kaźmierska, K. (2009). Między pamięcią zbiorową a biograficzną: Podróże do miejsc urodzenia izraelskich Żydów. In A. Szpociński (Ed.), Pamięć zbiorowa jako czynnik integracji i źródło konfliktów (pp. 34-35). Warszawa: Wydawnictwo Naukowe Scholar. 
Kaźmierska, K. (2004). Wywiad narracyjny jako jedna z metod w badaniach biograficznych. Przeglad Socjologiczny, 1, 71-96.

Kaźmierska, K. (1997). Wywiad narracyjny-technika i pojęcia analityczne. In M. Czyżewski, A. Piotrowski, \& A. Rokuszewska-Pawełek, Biografia a tożsamość narodowa (pp. 35-44). Łódź: Katedra Socjologii Kultury Uniwersytetu Łódzkiego.

Kubis, B. (2007). Poznawcze i kształcace walory literatury dokumentu osobistego (na przykładzie relacji Polaków wysiedlonych z Kresów Wschodnich oraz Niemców wysiedlonych ze Ślaska w latach 1944-1946). Opole: Wydawnictwo Uniwersytetu Opolskiego.

Kuziak, T. (1999). Dawno, to były czasy... Opowidania i humoresky z Łemkowyny. Krynica: Nasza Zahoroda.

Makuch, W. (2007). Z hlybyny sercia: Iz spohadiw deportowanoho Łemka. Lwiw: W. Makuch.

Maślej, A. (2008). Moja Łemkowszczyzna. Tryptyk. Warszawa: TYRSA.

Monczak, L., Połyniak, I., \& Juśkiw, N. (2006). Łabowa: Łemkiwśke seło naszoji pamiati, Iwano-Frankiwśk: Misto NW.

Murianka, P. (2007). A Wista dalej ptynie. Krynica - Legnica: Stowarzyszenie Łemków.

Muszynka, M. (2001). Łemko na foni Radocyny: Do 50-littia Wołodymyra Szurkała, Priasziw: Fundacja Karpaty.

Nijakowski, L. (2006). Domeny symboliczne: Konflikty narodowe i etniczne w wymiarze symbolicznym. Warszawa: Wydawnictwo Naukowe Scholar.

Ołenycz, I. (2003). Spohady z mołodych lit. Lwiw: Wydawnyctwo Mc.

Ołenycz, I. (1993). Dolia Łemkiwszczyny. Toronto: I. Ołenycz.

Prawda, M. (1989). Biograficzne odtwarzanie rzeczywistości (O koncepcji badań biograficznych Fritza Schütze). Studia Socjologiczne, 115 (4), p. 81-98.

Rauch, A. (1974). Wstęp: Świadectwo ludzi nieobojętnych. In A. Rauch (Ed.), Prace niesyzyfowe: Wybór pamiętników nauczycieli szkót wiejskich Rzeszowszczyzny. Rzeszów: Rzeszowskie Towarzystwo Przyjaciół Nauki.

Riemann, G., \& Schütze, F. (1991). "Trajectory" as a Basic Theoretical Concept for Analyzing Suffering and Disorderly Social Processes. In D.R. Maines (Ed.), Social Organization and Social Process: Essays in Honor of Anselm Strauss (pp. 333357). Series: Communication and Social Order. New York: Aldine de Gruyter. 
Sławiński, J. (2002). Autobiografia [entry]. In J. Sławiński (Ed.), Słownik terminów literackich (pp. 50-51). Wrocław - Warszawa - Kraków - Gdańsk - Łódź: Zakład Narodowy im. Ossolińskich.

Starczak-Wawryczyn, M. (2009). Seło Mszana na Łemkiwszczyni: Istorycznyj narys. Lwiw: Switowa federacja ukrajinśkych lemkiwśkych ob. 'jednan,' Instytut ukrainśkoji archeohrafiji ta dźerełoznawstwa im. M. S. Hruszewskoho NAN Ukrajiny. Lwiwśke widdiłennia.

Szczepański, J. (1971). Metoda biograficzna. In J. Szczepański, Odmiany czasu teraźniejszego (pp. 573-606). Warszawa: Książka i Wiedza.

Trzeszczyńska, P. (2010). Mniejszość sama o sobie: Łemkowie i Łemkowszczyzna w pamiętnikach (perspektywa antropologiczna). In B. Nitschke (Ed.), Europejskie stosunki narodowościowe: Aspekty duchowe i materialne (pp. 123-131). Zielona Góra: Wydawnictwo Majus.

Wojtkowiak, Z. (2003). Źródta narracyjne. Part I: Pamiętnik, tekst literacki. Poznań: Wydawnictwo Poznańskie.

Wozniak, S. (2010). Pereselenci: Istoryko-krajeznawczyj narys pro seło Biłcarewu powit Nowyj Soncz kołysznioho Krakiws'koho wojewodztwa (Łemkiws'kyj kraj). Hałycz: S. Wozniak.

Szlachcicowa, I. (2003). Trwanie i zmiana: Międzygeneracyjne różnice w strategiach opracowywania zmiany społecznej. In I. Szlachcicowa, Biografia a tożsamość (pp. 11-41). Wrocław: Wydawnictwo Uniwersytetu Wrocławskiego.

Thomas, W.I., \& Znaniecki, F. (1918). The Polish Peasant in Europe and America: Monograph of an Immigrant Group, Vol. III. Boston: Richard G. Badger/The Gorham Press.

Urbaniak-Zając, D., \& Kos, E. (2013). Badania jakościowe w pedagogice: Wywiad narracyjny i obiektywna hermeneutyka. Warszawa: Wydawnictwo Naukowe PWN.

Znaniecki, F. (1936). The Method of Sociology. New York: Farrar \& Rinehart.

Zwoliński, J. (1994). Rapsodia dla Łemków. Koszalin: J. Zwoliński 